\title{
AS IRRUPÇÕES DO FANATISMO Religioso NA MODERNIDADE
}

\section{Marcos Lobato Martins ${ }^{1}$}

\section{A} s sociedades atuais herdaram dos séculos XVIII e XIX dois conjuntos doutrinários que, no momento em que surgiram, despertaram grande entusiasmo. Trata-se do liberalismo e do progressismo. 0 primeiro, cujas origens remontam à época da Reforma (no século XVI), alcançou maior força teóricoprática no século XVIII, no âmbito do Iluminismo, gerando uma revolução filosófica, econômica e política. Já o progressismo é filho do século iluminista e tem o seu auge no século XIX. Ambos invadiram o século XX e abarcaram praticamente todo o planeta, difundidos pelo imperialismo e a expansão global do capitalismo.

0 século XVIII tornou irresistível a crença nos poderes da investigação científica experimental, nos direitos naturais do homem, no valor da livre iniciativa econômica e do livre cambismo, no individualismo ena secularização. As reivindicações fundamentais do liberalismo incluíam: a) o respeito às potencialidades do indivíduo, sem cerceamentos do Estado; b) a liberdade de expressão, de reunião e de opinião; c) o direito de propriedade e a diminuição de entraves legais à acumulação; d) o predomínio do contrato jurídicosocial, que deveria substituir os antigos privilégios sociais; e) a limitação da ação governamental, com a abolição do arbítrio por meio da real institucionalização jurídica; f) a defesa do governo representativo e da autodeterminação nacional e; g) a limitação da intervenção das religiões na vida social. ${ }^{2} \mathrm{Na}$ afirmação do ideário liberal, os homens do século XVIII travaram batalhas contra o poder das religiões instituídas, sobretudo a Igreja Católica. Queriam com isso, em primeiro lugar, promover a separação do poder político da legitimação religiosa, denunciando o reacionarismo da religião daquele tempo, como se pode ler no discurso de Robespierre à Convenção Nacional francesa: "Dizem-se [os reis] as imagens da Divindade... Será para torná-la odiosa? Dizem que a autoridade delesé Sua obra. Não: Deus criou os tigres; mas os reis são a obra-prima da concepção humana. Se 
eles invocam o Céu, épara usurpar a Terra; se nos falam da divindade, épara se colocarem no lugar dela: remetem a ela as preces dos pobres e os gemidos do infeliz; mas eles mesmos são os deuses dos ricos, dos opressores e dos assassinos do povo" ${ }^{3}$

Em segundo lugar, a batalha dos iluministas contra a religião objetivava enfraquecê-la como concepção de mundo. Os enciclopedistas e notadamente Voltaire procuraram mostrar que a religião consistia de meras superstições a serviço do poder, um amontoado de preconceitos e crenças absurdas que travavam o desenvolvimento social e cultural da humanidade. Força irracional associada a crimes terríveis, a religião deveria ceder espaço à racionalidade iluminista, aos saberes científicos è filosofia que avançavam por causa do esforço dos "modernos". Também deveria haver uma separação entre a ética e a religião, no sentido de que as condutas relativas à vida cotidiana precisariam encontrar justificativas racionais e não aquelas tradicionais, baseadas em idéias e crenças religiosas. Enfim, para os iluministas, a religião perdia o caráter de assunto de Estado para restringirse à esfera privada. Questão de livre escolha, de opinião e crença individual.

$\mathrm{Na}$ atmosfera cultural do Iluminismo, nasceu naturalmente o progressismo. Ao pronunciar na Sorbonne sua histórica conferência, intitulada "Uma revisão filosófica dos sucessivos progressos do pensamento humano", em 1750, Turgot dava início à trajetória do progressismo. 0 progresso tornou-se idéia-chave nos séculos XVIII e XIX, concebida como uma verdade eterna, baseada na própria natureza das coisas e dotada de absoluta evidência. 0 progressismo delirante difundiu-se entre reformadores sociais e políticos do século XIX, possuídos por uma confiança excessiva na total transformação da sociedade, da corrupção para a perfeição, da noite para o dia. Os homens do século XIX consideravam indiscutível (e irreversível) o avanço humano em termos pessoais e coletivos. Avanço linear, automático, resultado inexorável da liberdade e da racionalidade. Para os liberais, novos arranjos institucionais bastariam para gerar a convivência pacífica e feliz. Os socialistas do século XIX acrescentaram que o ambiente físico e as pressões econômicas também teriam que ser modificados para se alcançar a felicidade dos indivíduos. Mas mantiveram a crítica contra a religião, prevendo seu desaparecimento completo em decorrência da marcha de implantação do socialismo, encabeçada pelo movimento revolucionário do proletariado.

Com argumentos distintos, o sociólogo alemão Max Weber também asseverou que há uma tendência de perda de influência social da religião no mundo moderno. Para Weber, a modernidade é caracterizada pela secularização de todas as esferas da vida

3 RoBesPIERRE, M. Discursos e relatórios na Convenção. Rio de Janeiro: Eduerj/Contraponto, 1999. p. 124 
social. Ocorrem a separação do poder do Estado das instituições religiosas e a atrofia do campo religioso como resultado da "racionalização". O progresso da ciência e da técnica conduziria as pessoas a acreditarem que não há forças misteriosas agindo no mundo, de maneira que não é necessário recorrer a meios mágicos para dominar ou implorar aos espíritos. Esta tendência Weber chamou de "desencantamento do mundo". A racionalidade científica e a ação instrumental (adequação de meios a fins), ao abarcarem todas as esferas da vida social, tornariam mais excepcionais os comportamentos ancorados na tradição e em emoções/sentimentos profundos. A modernidade, na perspectiva weberiana, seria acompanhada pelo domínio do cálculo sobre tudo.

Nas décadas de 1960 e 1970, alguns sociólogos chegaram a formular a tese da secularização ampliada. Um destes sociólogos, assinalou o declínio do envolvimento popular com as igrejas, a perda de abrangência e influência das instituições religiosas, assim como da popularidade e do impacto das crenças religiosas. ${ }^{4}$

Ora, como compreender então que, segundo pesquisa do Datafolha, do jornal Folha de S.Paulo, realizada em 1995, tenha se encontrado apenas 4,9\% de eleitores brasileiros que admitiam não ter qualquer crença religiosa? ' Como explicar a pujança, no Japão atual, de um sincretismo que mistura fontes religiosas indianas, chinesas, coreanas e até mesmo cristãs? E a nova onda de influência da religião no mundo islâmico, a partir dos anos 1980? E as formas idiossincráticas e difusas de experiência com o sobrenatural que surgem nos cultos da "Nova Era"?

Esses fenômenos do final do século XX sugerem que está em curso um certo "reencantamento do mundo". Por outro lado, como enxergar hoje o progressismo, se 0 século XX configurou-se uma era de guerras, massacres, genocídios, exploração econômica, perseguições ideológicas, enfim, catástrofes humanitárias sem precedentes? Como lidar com o fato de que, mesmo no século XXI, as desigualdades sociais estejam ampliando e as injustiças se multiplicando? E por que a matança e a loucura prosseguem, amiúde fundamentadas na religião?

Há que se admitir que a aposta dos pensadores dos séculos XVIII e XIX no rápido progresso ético da humanidade e na perda também veloz de influência social da religião tenha sido ingênua e precipitada. 


\section{SeITAS DA Nova ERA}

Tempo de profundas transformações sociais, o século XIX foi época marcada pelo "renascimento religioso". Os altos custos em sofrimento humano do grande número de guerras, a começar pelas guerras napoleônicas; o crescimento da miséria e da exploração decorrente da expansão da Revolução Industrial, com suas cidades lúgubres e caóticas, apinhadas de trabalhadores famélicos; a rápida difusão da permissividade romântica propagandeada por Lord Byron, com sua amoralidade escandalosa; a vitória do liberalismo na esteira de um movimento intenso de crítica aos valores tradicionais, vitória acompanhada do conceito laissez-faire de competição - que John Stuart Mill chamou de "pisoteamento, esmagamento e acotovelamento" -; todos estes são fatores que, combinados, provocaram o surgimento de uma sensibilidade maior à dor e ao sofrimento das massas como nunca se vira anteriormente.

Especialmente entre os setores médios das sociedades européia e norte-americana, a reação ao novo ethos liberal da civilização urbano-industrial, tomou duas formas distintas: a solução socialista e a religiosa. Os socialistas denunciaram o mundo criado pela burguesia - no qual "não sobrou outro nexo entre os homens que o puro interesse social, o empedernido pagamento em dinheiro (...) o calculismo egoísta" - e 0 aprofundamento da desigualdade social, preconizando a luta política revolucionária dos operários como meio para superar definitivamente a exploração de muitos por poucos. Outros grupos preferiram enfrentar o avanço da sociedade liberal envolvendo-se com movimentos de renascimento religioso que se espalharam por muitos países, no decorrer do século XIX e início do século XX.

$\mathrm{Na}$ Grã-Bretanha, o renascimento religioso implicou o aumento do número de Igrejas estabelecidas, o surgimento de diversas ramificações evangélicas e de templos não-conformistas. Em 1830, o reverendoJ.N. Derby criou a seita dos Plymouth Brethren. Em 1878, como conseqüência das Missões Cristãs iniciadas pelo reverendo William Booth, foi constituído o Exército da Salvação, a seita britânica mais notável e de maior penetração, com sua mensagem espiritual e uma preocupação ética no plano prático, que chama atenção por causa de sua forma paramilitar de organização. No Irlanda do Norte, surgiu a Grande Renovação, movimento religioso que perseguiu uma reforma geral no caráter moral, a eliminação da embriaguez e da profanidade. Também apareceram a Renovação Galesa, com os cantos arrebatados nas capelas, e a fundamentalista Igreja Livre da Escócia. Ainda na Escócia, no ano de 1883, surgiu a Brigada dos Meninos, criada para o treinamento moral da juventude cristã. 
Na França, ocorreu o ressurgimento do catolicismo, marcado pelo aparecimento de Santa Bernadete e do novo culto da Virgem Maria centrado em Lourdes, em 1858. 0 humilde curé Santo André Fournet (1752-1834) fundou 60 conventos de Filhas da Cruz. Francisca Cabrini (1850-1917) fundou 54 casas das Irmãs do Sagrado Coração. Maria di Rosa (1813-1855) criou as Servas da Caridade para ajudar as operárias de Brescia.

Durante o século XIX, os Estados Unidos foram bastante prolíficos no ativismo reformador cristão. Em 1825, Charles Grandison Furney fundou uma seita em Nova Iorque, preconizando a vida útil (e não uma vida santa) e criando seu "banco dos réus para pecadores". Em 1830, Joseph Smith (1805-1844) desenvolveu a ética mórmon, logo após revelações e visões que teve sobre o "Livro de Mórmon", texto-base de sua doutrina, de importância igual à da Bỉblia. A Igreja Mórmon expandiu-se para Utah graças a Brigham Young (1801-1877), adotando ali um estilo de vida peculiar e altamente eficaz, com ênfase na cooperação e na eficiência econômica, que tinha a poligamia como um princípio (abandonado em 1887 para dirimir conflitos com o governo estadunidense). A expansão para o Oeste, no plano da religiosidade, forneceu o impulso para o chamado movimento de fronteira, que exigia uma simplificação extremada da teologia. No far west, a vida religiosa das comunidades esparsas de colonos girava em torno da pregação do arrependimento e da leitura da Bíblia. A Bíblia era tida como a biblioteca dos fiéis, isto é, como o depósito das verdades e dos saberes necessários à vida dos cristãos. E o mundo terreno era enxergado como o palco do combate perene do Bem contra o Mal. Dessa forma, nas comunidades isoladas e autogestadas do Oeste americano a leitura fundamentalista da Bíblia tornou-se regra, conformando os códigos de conduta que deveriam ser seguidos rigidamente por seus integrantes.

Tanto na Europa quanto nos Estados Unidos, o renascimento religioso do século XIX espalhou novos padrões de vivência religiosa, baseados na valorização dos sentimentos e das experiências individuais, uma religiosidade que se aproximava do irracional e rejeitava muitos aspectos da modernidade. Essa tendência alcançou o auge com 0 fenômeno das igrejas pentecostais, cujo surgimento, nos Estados Unidos, no início do século XX, foi avassalador. As testemunhas de Jeová, os Adventistas do Sétimo Dia, A Assembléia de Deus e linhas da Igreja Batista arrebanharam principalmente negros e pobres, com uma teologia simplificada e uma atitude fundamentalista. Aversão aos valores modernos, ênfase na família e na virgindade, obsessão com a justificativa bỉblica (a utilização de versículos das Escrituras para justificar atos e condutas), preferência pelos textos de guerra do Antigo Testamento. Nessas igrejas congregacionistas, portanto, 
floresceu uma visão militarista de Deus e desenvolveu-se o germe da intolerância religiosa. Seus fiéis posicionaram-se, no decorrer do século XX, contra as lutas pelos direitos humanos e as liberdades civis, lanç̧aram anátemas contra os defensores do aborto e combateram 0 homossexualismo.

Compreende-se, dessa maneira, porque no início do século passado o termo fundamentalismo era aplicado às novas seitas cristãs. Nos anos 1920, chamava-se de fundamentalismo a corrente teológica de origem protestante, desenvolvida nos Estados Unidos especialmente durante a I Guerra, que admite apenas o sentido literal das Escrituras, opondo-se a toda interpretação histórica ou científica e professando o fixismo. As seitas cristãs fundamentalistas americanas, desde então, dividiram-se em dois grandes grupos. Aquelas que assumiram uma atitude isolacionista, formando pequenas comunidades auto-centradas, como o grupo Amish (cujos integrantes não reconhecem o Estado, não pagam impostos, não usam tecnologias modernas, não comem alimentos que não são mencionados na Bíblia). E as seitas dominadas por uma atitude missionária instrumental, que buscam expandir valores fundamentalistas até mesmo por meio da conquista do poder político.

Entretanto, no decorrer do século XX, a dramaticidade e a carga de violência existentes em diversos acontecimentos no norte da África (Nigéria, Argélia e Egito), no Líbano, na Palestina, na Arábia Saudita, no Irã e no subcontinente indiano, nos quais a participação de grupos radicais islâmicos foi decisiva, promoveu uma mudança de sentido no termo fundamentalismo. Para as populações ocidentais, fundamentalismo passou a ser identificado com islamismo e a carregar um quê de fanatismo religioso ou mesmo violência sacra. 0 conceito de fundamentalismo passou a ser empregado para explicar comportamentos e ações intransigentes por parte dos grupos islâmicos, principalmente depois da vitória dos aiatolás iranianos sobre o xá Reza Pahlevi, em 1979. Por influência da mídia, o Ocidente praticamente fechou os olhos para seus próprios fundamentalistas e fanáticos religiosos, para enxergar somente o fundamentalismo exótico que vinha do mundo islâmico, principalmente do Oriente Médio. 0 terrorismo da rede Al Quaeda, sobretudo após os ataques de 11 de setembro de 2001 contra as torres gêmeas de Nova Iorque e o prédio do Pentágono, na capital dos Estados Unidos, deu tons ainda mais fortes à caricata identificação entre Islã e fundamentalismo.

É necessário enfrentar esse equívoco. Conforme o antropólogo inglês Ernest Gellner, o fundamentalismo pode ser entendido como a rejeição do relativismo na interpretação dos textos sagrados, acompanhada da exigência do cumprimento integral de uma orientação ou da observância de todo um sistema de conduta, que ganha sentido na sua 
totalidade integradora, permitindo a manutenção da identidade religiosa. ${ }^{6}$ Para este autor, o fundamentalismo estabelece como meta a invocação de um passado no qual se encontra a origem do sistema religioso, visto como a Idade de Ouro. Dessa forma, segundo Gellner, o fundamentalismo estaria presente em muitas religiões, mas se encontraria no apogeu no Islã. Antes de discutir a afirmação de Gellner sobre 0 fundamentalismo islâmico, convém examinar alguns episódios terríveis provocados pelo fanatismo religioso, nos séculos XIX eXX.

Séculos depois de encerradas as Cruzadas e as perseguições da Inquisição aos "infiéis", a cristandade continuou capaz de promover matanças cruéis, motivada pela fé. Essas matanças, na qual o elemento religioso desempenha papel relevante, tiveram causação complexa, misturando ressentimentos nacionais, ódios políticos, iniqüidades sociais, ambições imperiais, etc.

No fim do século XIX, a Rússia foi conturbada pelos pogroms, os massacres de judeus executados por cristãos ortodoxos. Ameaçados pelas rebeliões de camponeses e trabalhadores, os czares procuraram desviar a atenção do povo estimulando grupos antisemitas a insuflar o ódio ortodoxo contra os judeus. Em 1882, ocorreu o assassinato do czar Alexandre II por jovens niilistas lançadores de bombas. Um dos seis rebeldes condenados à morte pelo atentado era uma jovem judia, fato que o governo czarista aproveitou para reviver 0 anti-semitismo latente. Turbas de cristãos ortodoxos invadiram comunidades judias na Rússia, pilharam propriedades e espancaram judeus. Em seguida, o governo russo aprovou duras leis anti-semitas e os 35 mil judeus de Moscou foram expulsos.

Em 1903, outro pogrom teve início na Rússia. 0 governo czarista, em estreita articulação com a alta hierarquia da igreja Ortodoxa, difundiu pela imprensa a idéia de que as agitações pré-revolucionárias que assolavam o país eram fruto de "manifestações judias". Paradas e comícios foram classificados pelo governo como "manifestos judeus", com o propósito de dissuadir os russos ortodoxos de se juntar às agitações. Como resultado dessa manobra diversionista, começaram os ataques aos bairros judeus. Na cidade de Odessa, houve 300 mortos; em Yekaterinoslav, 120 mortos e muitos outros mais, em centenas de cidades. Os panfletos incitando os pogroms tinham sido impressos numa tipografia da polícia secreta czarista.

Nem mesmo a Revolução Bolchevique de 1917 interrompeu a terrível tradição de perseguição contra os judeus na Rússia. Ao contrário, o Exército Vermelho cometeu alguns massacres, sob o slogan "ataque aos burgueses e os judeus". Mas foram o Exército

6 Cf. GELLNer, E. Pós-modernismo, razão e religião. Lisboa: Instituto Piaget, 1992. pp. 14ss. 
Branco anticomunista e as tropas ucranianas de cossacos que trucidaram milhares de pessoas nas cidades judias. 530 comunidades judias foram atacadas e cerca de 60 mil judeus mortos.

À primeira vista, os pogroms não eram religiosos. Porém, observadas mais de perto, essas ondas de ataques odiosos contra os judeus refletiam a divisão religiosa da sociedade russa, na qual predominava a fé ortodoxa, e o ódio tradicional que os cossacos ucranianos, os camponesese os padres ortodoxos alimentavam em relação aos judeus. Os pogroms mostraram que ainda estava bastante vivo o desprezo que, desde os tempos medievais, os cristãos tinham pelos judeus, os quais haviam rejeitado como párias da religião, chamado-os de os "matadores de Cristo" ou os "inimigos de Deus". Ospogroms russos dos séculos XIX e XX fazem parte de uma longa herança cristã de doutrinação e prática contra os judeus.

Outro episódio de violência massiva, decorrente de arraigados ódios religiosos, nacionalistas e étnicos, foi o horror armênio que matou mais de um milhão de cristãos e muçulmanos durante a I Guerra. A Armênia era um enclave cristão no mundo mulçumano, parte componente do Império Otomano desde o século XVI. Na Armênia, uma maioria cristã convivia de modo tenso com uma minoria islâmica. No fim do século XIX, missionários protestantes conseguiam muitas conversões na Armênia e isto provocou o acirramento da rivalidade entre grupos ortodoxos e católicos que viviam na região. Surgiu então um movimento para criar uma Armênia cristã independente. Na década de 1890, começaram os massacres e o combate armado, que teriam matado 200 mil armênios. Em 1909, novo episódio de horror, produzindo cerca de 20 mil mortos.

Com a I Guerra, os Armênios cristãos receberam o apoio da Rússia, que lutava contra a Alemanha, a liada do Império Otomano. Os cristãos rebelaram-se contra a Turquia e massacraram muçulmanos. Na cidade de Van, queimaram a parte mulçumana e mataram 30 mil pessoas. A reação da Turquia foi imediata e violenta. 0 Exército turco atacou os cristãos armênios e realocou a força as comunidades armênias. Calcula-se que, entre 1915 e 1920, foram mortos 600 mil armênios e 2,5 milhões de muçulmanos, numa guerra intercomunidades travada por forças irregulares mulçumanas e cristãs. Séculos depois das Cruzadas, a Ásia Menor tornou-se cenário de genocídios, de enfrentamento sanguinário de cristãos e muçulmanos?

Estes episódios de violência envolvendo cristãos são pouco conhecidos da opinião pública mundial. Todavia, algumas manifestações recentes do fanatismo cristão, mesmo

\footnotetext{
Em 1988, tumultos entre armênios cristãos e muçulmanos xiitas do Azerbaijão duraram 11 meses, causaram mais de 100 mortes e 0 envio de tropas soviéticas para o local.
} 
causando número muito menor de vítimas, geraram forte comoção em decorrência da cobertura de mídia que receberam. É o caso do suicídio coletivo dos seguidores do Templo dos Povos, em Jonestown, na Guiana, em 1978. Um tipo diferente de horror religioso que espantou o mundo.

A tragédia, que matou 914 pessoas (dentre as quais quase 300 crianças), foi responsabilidade de um só ministro, o reverendo Jim Jones. Ainda jovem em Indiana, EUA, Jones fundou o Templo dos Povos, uma congregação multirracial de pobres. Fornecia sopa para os necessitados, asilo para os velhos, roupas para os maltrapilhos e liderou campanhas para combater a segregação racial. Jones adquiriu fama, ao ponto de tornar-se, em 1961, chefe da Comissão de Direitos Humanos de Indianápolis. Então Jones se proclamou profeta de Deus, depois, o próprio Jesus Cristo. Realizou milagres, executando formas de cura pela fé. Chegou a pregar que o mundo acabaria no dia 15 de julho de 1967. Por volta de 1964, Jones mudou-se para a zona rural de Ukiah, na Califórnia, acompanhado por 150 seguidores. Em 1971, a congregação mudou-se outra vez, para um bairro negro de São Francisco. Oferecendo vários serviços sociais, o Templo dos Povos cresceu rapidamente, alcançando $20 \mathrm{mil}$ seguidores. 0 reverendo Jim Jones ganhou prestígio, inclusive junto ao governador Jerry Brown e ao prefeito George Moscone.

Mas começaram a surgir rumores inquietantes sobre o Templo dos Povos: violência contra crianças, abusos sexuais, apropriação dos bens e dos cheques dos seguidores adultos, etc. Jim Jones e muitos de seus seguidores começaram a passar grande parte do tempo na Guiana, na colônia de Jonestown. Em 1977 e 1978, as denúncias contra o Templo dos Povos aumentaram na imprensa americana. Parentes de residentes em Jonestown solicitaram ao Secretário de Estado Cyrus Vance e ao Congresso ajuda para remover seus familiares daquele "campo de concentração".

A visita de uma comissão americana a Jonestown, integrada pelo deputado Leo Ryan e por funcionários do Departamento de Estado, repórteres e parentes dos colonos, em novembro de 1978, precipitou a tragédia. No segundo dia de visita à colônia, quando se preparavam para regressar levando consigo colonos que imploraram para sair, os membros da comissão foram atacados a tiros. Morreram cinco pessoas, inclusive o deputado Ryan. Onze pessoas foram feridas e as demais fugiram para a selva. Na colônia, o reverendo Jones reuniu seus seguidores, anunciou a execução da comitiva do congressista e disse aos fiéis que era hora do suicídio em massa. Segundo o The Sunday Times, Jones teria declarado: "Se vocês me amam tanto quanto eu amo, devemos todos morrer ou ser destruídos de fora para dentro". 
Os fiéis do Templo dos Povos de Jonestown ingeriram refresco de fruta com cianeto; Jim Jones matou-se com uma bala na cabeça. Um punhado de membros escapou para a selva e sobreviveu.

Na tragédia de Jonestown, o fanatismo mostra-se por inteiro. Na paixão cega que leva centenas de pessoas a excessos - provocar a própria morte e a de outros indivíduos - em favor de uma religião. Na ação delirante de um líder que se julga inspirado pela divindade.

Em Waco, Texas, o fanatismo dos seguidores da seita cristã Ramo Davidiano provocou, nos anos 1990, a morte de quase uma centena de pessoas. Em 1934, um grupo de Adventistas do Sétimo Dia fundou ali uma comunidade conhecida como Monte Carmel. A comunidade possuía um centro de estudos teológicos e levava uma vida autônoma, sem conflitos com as autoridades e os habitantes de Waco. 0 líder fundador de Monte Carmel era reverenciado como um profeta, e anunciava a volta de Jesus Cristo. Em 1983, a facção denominada Ramo Davidiano Águas Vivas passou a controlar a comunidade, sob a liderança de David Koresh.

Koresh profetizou que seus seguidores entrariam em conflito com forças do governo dos Estados Unidos no ano de 1995. Em razão de tal profecia, os integrantes de Monte Carmel começaram a estocar grande quantidade de armas, situação que despertou a atenção do governo. Em fevereiro de 1993, agentes chegaram a Monte Carmel para dar ordem de prisão a Koresh, acusado de posse ilegal de armas. Houve tiroteio, provocando a morte de quatro agentes e de seis seguidores de Koresh. 0 FBI cercou a comunidade, mas Koresh não se entregou, declarando que Deus the aconselhara aguardar. 0 líder de Monte Carmel fez uma série de sermões, anunciando o final dos tempos. 0 cerco do FBI arrastouse até meados de abril de 1993, quando as forças do governo tentaram invadir Monte Carmel. Ocorreu então um incêndio, no meio de intenso tiroteio, resultando na morte de 80 pessoas, incluindo Koresh.

A África também foi berço de seitas cristãs fundamentalistas. Uma delas, 0 rastafarismo, está associada à resistência liderada pelo Imperador Hailé Selassié (1891-1975), conhecido como Ras Tafari, contra a conquista italiana da Etiópia. Em torno da figura do Imperador surgiu um novo cristianismo africano, ou melhor, um movimento místico que pregava que os rastafarianos seriam os verdadeiros judeus, negros por causa dos pecados do passado, e a Etiópia seria a terra prometida. Os rastafarianos eram antipermissivos, antibrancos e militantes, embora considerassem aceitáveis drogas leves como a "Cannabis". 0 movimento adquiriu força na Jamaica, a partir da qual espalhou-se pelas Antilhas de língua inglesa, 
tornando-se um movimento cultural e político, além de religioso ${ }^{8}$. Outra seita cristã, militante, conservadora e puritana surgiu no Congo, em 1921. Foi fundada por Simon Kimbangu (1890-1951), no bojo da reação à opressão belga. Os seguidores de Kimbangu rejeitavam o álcool, o tabaco, a dança e a poligamia. Também na África, o profeta zulu Isaías Shembe (1880-1935) fundou a igreja dos nazaritas, em 1911, dotada de ética fundamentalista e puritana.

\section{LinHAgENS ORIENTAIS E Fundamentalismo IsLÂMico}

0 imperialismo europeu estendeu suas conquistas até a Ásia, alcançando a China e o subcontinente indiano. Populações numerosas e diversas, dotadas de culturas milenares e sofisticadas, tiveram que dobrar-se à exploração econômica européia, seja na forma de protetorados ou de simples domínio colonial. Os problemas de aculturação resultantes desse processo adquiriram, em muitas ocasiões e em diversos lugares, grande intensidade. Os valores europeus chocaram-se com as tradições dos velhos povos asiáticos.

Um dos efeitos dessa situação de "fricção cultural" foi uma grande efervescência de idéias no seio das religiões orientais. Em 1844, Sayyid Ali Muhammad se declarou, no Irã, o bab anunciador em contato com o imã oculto, e foi executado por heresia. Um dos seus seguidores, Mirza Husein Ali Baha Ullah (1817-1892) recebeu a revelação de que aquele era o eleito de Deus, fazendo parte de uma linhagem inacabada de profetas que incluía Jesus, Krishna, Maomé e outros. Mirza Husein Ali viajou, em 1863, para Bagdá, onde fundou o bahaísmo, uma ramificação do islamismo que enfatiza a concordância entre a ciência e a religião, promovia a igualdade, a paz, a educação, o bem-estar, o direito ao trabalho e a libertação das mulheres de sua sujeição tradicional. Baha Ullah autoproclamou-se novo emissário divino, foi preso pelos turcos e enviado para uma prisão em Acre, onde morreu em 1892. A nova fé Baha'i era uma religião vigorosa e bastante atualizada, muito mais liberal do que o islã normativo. Porém, como se mostrará adiante, foi perseguida pelos muçulmanos xiitas do Irã.

Também o hinduísmo foi modernizado primeiro por Anya Sanaj (18281883) e, depois, por Sri Rama Krishna Para ma ham (1836-1886), chamado de o "Wesley hindu". Eles perseguiram o ideal da compaixão, promoveram aproximações

8 Os rastafáris da Jamaica acreditam que o país representa sua própria "Babilônia", e que eles formam uma das tribos perdidas de Israel. Por meio da música (o reggae) e dos costumes (cabelos trançados, por exemplo), os rastafáris divulgaram o movimento místico e político dos negros jamaicanos. 
entre 0 racionalismo e a teologia do hinduísmo tradicional. Rama Krishna deu 0 importante passo de concluir que todas as religiões eram na verdade muito semelhantes e que todos os deuses eram "o mesmo Rama com mil nomes, assim como a água tem diferentes nomes em diferentes línguas".

No lado islâmico da Índia, Mirza Ahmad (1839-1908) foi o liberalizador do Islã, tarefa para a qual contou com a ajuda do pensador mulçumano Mohammed Iqbal (1876-1938), que defendia a igualdade para as mulheres e rejeitava a mitologia corânica. 0 budismo também produziu líderes modernizadores e o sikhismo encenou um renascimento no século XIX, especialmente com a fundação da Sociedade Singh, em 1873, na região de Amritsar.

Nessa tradição de modernização religiosa situaram-se dois grandes líderes indianos do século XX. 0 primeiro deles é Mahatma Gandhi (1865-1948), que dava igual valor ao Corão, à Bîblia e às escrituras hindus, além de sonhar com um Estado indiano integrado, sem divisões entre hindus e muçulmanos. ${ }^{9} 0$ outro líder foi Mohammad Al Jinnah (1876-1948), condutor de 90 milhões de muçulmanos em jornadas que afirmavam que os dois deuses eram um e que 0 amor deveria substituir a cobiça.

Todavia, como mostra o martírio de Gandhi, as correntes modernizadoras das religiões orientais encontraram forte resistência no subcontinente indiano. Ódios religiosos, humilhações coloniais, fervor nacionalista, apego às tradições e incompreensões geraram explosões de violência. Um exemplo sinistro é o Motim dos Sipaios, ocorrido na Índia em 1857, deflagrado pela combinação de tabus religiosos hindus e muçulmanos. A Companhia das Índias, que governava a então colônia britânica da Índia, empregava 250 mil mercenários nativos, chamados sipaios. Estas tropas foram armadas com rifles Enfield que usavam cartuchos untados com sebo animal, embrulhados em papel, que tinham de ser abertos com os dentes. Isso enfureceu os sipaios hindus (porque consideravam as vacas sagradas) e os muçulmanos (porque consideravam os porcos animais impuros).

A revolta começou em Meerut. A cidade foi devastada pelos sipaios e todos os europeus que encontraram foram mortos. Os rebeldes seguiram para Déli, onde mataram os europeus. Em Kanpur, no Vale do Ganges, massacraram os soldados ingleses, suas mulheres e filhos. A custo os ingleses conseguiram vencer os sipaios hindus e muçulmanos, contando com a providencial lealdade dos sipaios sikhs da região do Punjab, que odiavam os revoltosos. A repressão britânica ao motim foi bárbara.

9 Cf. Van Der Veer, P. Religious Nationalism: Hindus and Muslins in India. Berkely: University of California, 1994. 
Adharmiklarai ("violência religiosa") aumentou na Índia durante o processo de independência do país. Já na década de 1930, ocorreram em muitas cidades tumultos fatais entre muçulmanos e hindus. Estes conflitos prosseguiram depois da II Guerra, fato que levou a Grã-Bretanha a criar a Índia para os hinduse o Paquistão para os muçulmanos. Teve início, então, um gigantesco movimento de migrantes hindus que saíam do Paquistão para a Índiae, no sentido contrário, de muçulmanos da Índia para o Paquistão. 0 ódio religioso das multidões migrantes que se cruzavam nas áreas fronteiriças explodiu em massacres. Calcula-se que um milhão de pessoas morreram no desmembramento da antiga colônia, entre as quais o próprio Gandhi, assassinado por um hindu que o considerava excessivamente pró-muçulmano. As hostilidades envolveram também os sikhs, que ampliaram a matança sob o comando de Tara Singh.

Desde o final da década de 1940, a matança religiosa desencadeada por fanáticos hindus, muçulmanos esikhs não cessou. Os incidentes se sucedem, motivados por pretextos diversos. Em 1980, em Moradabad, tumultos entre hindus e muçulmanos mataram mais de 200 pessoas. 0 motivo foi um porco que atravessou solo sagrado muçulmano, que teria sido conduzido por hindus, conforme acusação dos muçulmanos. Em 1983, os confrontos entre estes dois grupos ocorreram na província de Assam, deixando 2 mil mortos. Em 1984, na região de Bombaim, novos confrontos de multidões armadas causaram mais de 200 mortose 13 mil desabrigados. A razão do episódio: um líder hindu pronunciou um discurso antiislã, que os muçulmanos responderam com um insulto religioso - penduraram sandálias sujas sobre o retrato do líder hindu. Em 1989, houve conflito em Indore, com o saldo de pelo menos 15 mortes. No ano de 1992, em Ayodhya, explodiu outro conflito entre hindus e muçulmanos, com mais de 10 mil mortes. Nesse último episódio, a batalha entre hindus e muçulmanos ocorreu em função de uma disputa de solo sagrado. Os hindus tentaram construir um templo sobre o local onde acreditam ter nascido Lorde Rama, mas os muçulmanos se recusaram a demolir uma mesquita que existe nesse lugar.

0 radicalismo sikh na década de 1980 transformou-se em terrorismo e gerou milhares de vítimas. Os seguidores sikhs de um pregador fundamentalista, Jarnail Bhindranwale, tentaram criar o Kalistão (a "terra dos puros"), uma teocracia independente na região de Punjab. Estimulados pelo líder Bhindranwale, que ensinava que os sikhs têm "a obrigação religiosa de enviar seus oponentes para o inferno", os fanáticos sikhs atacaram e mataram famílias hindus. Em 1984, os extremistas sikhs entrincheiraram-se no Templo Dourado de Amritsar, o santuário mais sagrado dos sikhs. 0 Exército indiano, por ordem da primeira-ministra Indira Gandhi, desocupou o templo. 
Na luta morreram mil pessoas, inclusive Bhindranwale. Então os sikhs da guarda pessoal de Indira a assassinaram, o que desencadeou a ira dos hindus. Em três dias, 5 mil sikhs foram mortos brutalmente por turbas de hindus.

Ate hoje, o terrorismo sikh continua ativo, colocando bombas em aviões indianos, assassinando hindus desprevenidos em emboscadas em casamentos, festivais religiosose encontros familiares. Os ataques ocorrem principalmente no Punjab. Jána Caxemira, a violência entre radicais hindus e muçulmanos continua produzindo vítimas e levando Índia e Paquistão a aproximarem-se perigosamente do estado de guerra.

Háno cenário político contemporâneo da Índia o avanço de um fundamentalismo nacional-hindu, que luta pela dessecularização da sociedade e a transformação do país numa comunidade na qual os muçulmanos serão cidadãos de segunda classe. Esse movimento está alicerçado no Bharatiya Janata Party (BJP), que assumiu o poder em 1998, com o primeiro-ministro Atal Behari Vajpayee. Uma vez no poder, o BJP tornou-se mais moderado; contudo. Grupos extremistas hindus continuam a pressionar pela implantação de seu programa.

Nem mesmo o país mais rico e moderno da Ásia escapou ao horror provocado por cultos "destrutivos". Em março de 1995, a seita japonesa chamada Verdade Suprema, liderada por Shoko Asahara, realizou atentado com gás Sarin contra o metrô de Tóquio, matando imediatamente quatro pessoas e ferindo milhares de outras. Mais tarde foi descoberto que o líder Asahara ordenara o seqüestro e assassinato, em 1989, de um advogado contrário àseita, e que integrantes da Verdade Suprema realizaram, em junho de 1994, atentado com gás Sarim na cidade de Matsumoto, no qual morreram sete pessoas.

A seita Verdade Suprema, fundada em 1984 por Asahara quando retornou de uma viagem de "iluminação" à Índia, misturava interpretações idiossincráticas do Ioga, do Budismo, do Cristianismo e atéde escritos de Nostradamus. Em 1992, Asahara publicara um livro no qual dizia ser ele próprio o Cristo, o único "mestre iluminado" do Japão e 0 "Cordeiro de Deus". Sua missão pessoal seria a de "carregar" os pecados do mundo, afastar o carma ruim de seus seguidores e transferir-lhes poder espiritual. Para o líder Aum, havia conspirações globais orquestradas por judeus, religiões japonesas rivais e maçons. Por meio do rádio, a seita chamava os Estados Unidos de "a besta do Livro das Revelações" e predizia que a América atacaria o Japão. E divulgava uma profecia apocalíptica: o fim seria anunciado por uma erupção no Monte Fuji e um ataque de gás sobre Tóquio; haveria, em seguida, um Armagedon nuclear, extinguindo a humanidade. A missão da seita era não apenas pregar a palavra da "salvação", mas também sobreviver ao "fim dos tempos". 
Os esforços dos membros da Verdade Suprema para realizar a profecia de Asahara promoveram o recrutamento de especialistas da comunidade científica japonesa e 0 desenvolvimento de armas químicas e biológicas. 0 ataque com gás contra Tóquio supostamente seria a faísca que faria explodir o conflito final da visão profética de Asahara. Na última mensagem gravada do líder para seus seguidores, eles foram convocados a realizar seu plano para a "salvação" e para "encontrar a morte sem arrependimentos". 0 caso da seita Verdade Suprema fornece uma advertência: grupos fanáticos têm clara disposição para tornar auto-realizáveis as predições apocalípticas de seus líderes.

Para muitos ocidentais, o mundo muçulmano vegeta na pobreza porque sua cultura seria arcaica, repressiva, imobilista e estaria inoculada pelo veneno de não acreditar no indivíduo, na liberdade e na democracia. Os governos autoritários e as elites corruptas dos paises muçulmanos, além de alimentarem o atraso do mundo islâmico, estariam criando o caldo de cultura necessário para que a nova face do mal que ameaça a civilização se desenvolva: o islamismo radical. A pátria da intolerância e do fanatismo religioso seria o Islã, porque estaria escrito no "código genético" do islamismo ser uma religião agressiva e fundamentalista.

É verdade que a segunda maior religião do mundo empreendeu guerras sangrentas para crescer. 0 profeta Mohammed (Maomé) conquistou Meca pela força, lutou nove batalhas e ordenou várias outras. Enfrentou os ricos de Meca, que ameaçaram constantemente sua vida, bem como as tribos beduínas da Península Arábica que lutavam entre si há séculos. Foi a nova fé anunciada por Mohammed que unificou a Arábia. Depois da morte do Profeta, em 632, seus sucessores - os califas - promoveram a expansão da fé islâmica por meio de guerras de conquista, as guerras santas ou Jibads ("lutas pela causa de Deus"). Primeiro conquistaram a Síria, o Iraque, a Palestina, o Egito e a Pérsia (atual Irã). Depois, lançaram-se para o Oriente, chegando até a Índia, e para o ocidente, dominando o norte da África e a Península Ibérica. É preciso considerar, contudo, que tanto o Corão quanto a Sunna proíbem as conversões forçadas e atribuem direitos e deveres aos que integram os povos do Livro (cristãos e judeus), chamados dhimmi ("protegidos pelo Estado Islâmico"). Por isso, havia boa dose de tolerância religiosa nas áreas dominadas pelos muçulmanos, de que é prova o esplendor cultural de Toledo, na Espanha medieval.

Simultaneamente à expansão do Islã, tiveram início lutas e divisões internas na Umma ("a comunidade muçulmana"). Os xiitas, seguidores de Ali, genro de Mohammed, lutaram guerras perdidas contra a maioria sunita. Os ultrafanáticos azariquis atacavam os "pecadores" e suas famílias. Nos séculos XII e XIII, uma pequena seita 
ismaelita, conhecida pelo nome de Assassinos, enfrentou violentamente os califas sunitas. Em missões suicidas, matadores solitários enviados pela seita mataram homens santos, estadistas sunitas, generais e dois califas. Durante as Cruzadas, os Assassinos fizeram dois atentados contra Saladino, sem êxito, e mataram o comandante cristão Conrad de Montferrat. A seita operava a partir de uma rede de fortalezas situadas nas montanhas do Irãe do Iraque. Sobre os Assassinos, Marco Pólo escreveu que se dava haxixe aos membros da seita para que agissem sem pensar.

No século XVIII, surgiu o grupo dos muçulmanos wahabis na Península Arábica. 0 fundador da seita foi Mohammed al-Wahhab, pregando que o Islã havia sido corrompido pela mundanidade e deveria ser purificado pelo fogo ${ }^{10}$. Wahhab declarou guerra contra "os infiéis" — nesse caso, os próprios muçulmanos. Após a morte do líder, exércitos de beduínos wahabis conquistaram diversas cidades da Península Arábica, massacrando os habitantes, no inicio do século XIX. Os turcos e os egípcios atacaram e derrotaram os wahabis, dispersando-os. A fermentação fanática dos membros da seita não cessou. No início do século XX, os "irmãos" fanáticos wahhabis dominaram toda a Arábia e criaram o moderno reino da Arábia Saudita, em 1934.

$\mathrm{Na}$ África oitocentista, seguidores do Islã provocaram ondas de violência. Em 1804, Usman dan Fodio, um religioso nigeriano, lançou uma jihad contra o sultão de Gobir. A luta durou quatro anos, resultando na queda do sultão e em milhares de mortos. Em 1854, na atual República do Mali, o líder religioso Umar al-Hajj lançou uma iibad contra os povos pagãos e os muçulmanos da etnia fulani. À frente de 10 mil homens, Umar al-Hajj aterrorizou a região, decapitou oponentes, realizou massacres, ate ser derrotado e morto numa caverna. Na segunda metade do século XIX, a África Central foi o palco de diversas revoluções islâmicas iniciadas por meio da jibad. Esses movimentos estavam associados à penetração ocidental no continente, que era vista pelos mulçumanos como o início da Era da Decadência, resultando na perda da identidade religiosa e da soberania política. No Sudão, ocorreu a mais espetacular dessas revoluções islâmicas. Por volta de 1880, o religioso Muhammad Ahmad se autoproclamou o Mabdi ("aquele que é divinamente guiado" e que será o restaurador da fé) e declarou uma jibad contra os egípcios, os europeus e os potentados africanos que se sujeitaram à intervenção ocidental. Os combatentes de Ahmad destruíram um exército egípcio de 10 mil homens, invadiram Cartum e massacraram seus defensores, inclusive o general inglês "Chinese" Gordon. 0

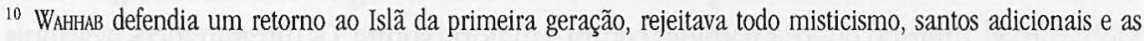
idéias incorporadas desde a morte do Profeta. 0 wahhabismo tornou-se um foco para o protesto contra a infiltração européia. Produziu os mujahadin ("guerreiros santos") da Índia e do Afeganistão. 
sucessor do Mabdi tentou declarar guerra contra todo o mundo islâmico, mas acabou vencido por forças anglo-egípcias numa campanha sanguinária. Um pelotão liderado por Sir Herbert Kitchener - no qual atuava o jovem oficial Winston Churchill - metralhou 20 mil "madistas" sudaneses em um único dia.

Vale lembrar que, em decorrência dos encontros com a cultura e a economia do Ocidente, outras partes do mundo islâmico produziram movimentos de reforma, de natureza muito distinta dos ressurgimentos fundamentalistas liderados pelos mahdis. Uma vertente do reformismo foi a corrente otomana de que o renascimento do Islã deveria vir pela via da política, na busca da conciliação da modernidade ocidental com a doutrina muçulmana. Assim, no século XIX, a Turquia lançou uma série de reformas legais. 0 resultado foi o surgimento de um sistema com dois níveis: a lei sagrada, que se aplicava aos assuntos particulares, e o direito público, que era secular. E buscou-se traduzir para a linguagem islâmica algumas categorias tipicamente européias. Um exemplo disso foi a prática corânica da Shura ("consulta aos crentes"), redefinida como a forma moderna que a democracia assumiu no mundo muçulmano. 0 movimento dos Jovens Turcos acabou transformando a Turquia numa exceção no mundo islâmico, porque, depois da deposição do califa, Mustafá Kemal "Ataturk" implantou a separação de religião e Estado e, em 1926, ocorreu a substituição da shariah ("a jurisprudência" derivada dos textos sagrados) por um código civil que julga as pessoas segundo uma lei comum, independentemente de religião.

0 exemplo da Turquia mostra que não há como imputar ao islamismo, tout court, uma inclinação atávica para o arcaísmo, o imobilismo e o radicalismo. Porque há um Islã pacifista, moderado, cosmopolita, ilustrado. 0 Islã de Ibn Ruchd ou Averróis (1126-1198), o maior filósofo de Córdoba, que desejava combinar a religião com o pensamento filosófico e científico. 0 Islã do sufismo, que incentiva a reclusão e a meditação, a vida ascética e a crença num Deus amoroso com quem o homem pode alcançar a união mística, cujo maior expoente foi Halladj (858-922), executado em razão de intrigas da corte abássida de Bagdá. 0 Islã apreciador de imagens que havia no Afeganistão do século 15. Tolerante e moderada também era a atitude do islamismo defendido por Al Jinnah, o líder muçulmano na Índia às vésperas da independência. $\mathrm{Na}$ cosmopolita Sarajevo, os mulçumanos conviviam bem com diferentes religiões, num clima de paz rompido tragicamente pelos ataques do Exército e das milícias sérvias no início da década de 1990. Com gosto pela liberdade e respeito às mulheres, o islamismo professado pelo comandante Massoud - líder afegão morto pelo Taleban em 2001 - 
destoava inteiramente do clima de opressão e fanatismo fundamentalista que imperava no regime chefiado pelo Mullah Omar.

0 Islã moderado sempre teve inimigos, numerosos e poderosos. Os muçulmanos fanáticos mostraram-se especialmente ativos no século XX. Um exemplo destacado é a Irmandade Muçulmana, movimento político-religioso sunita que defende um regime islâmico conforme a shariah e preconiza a solidariedade de todos os muçulmanos do mundo. Fundada no Egito em 1928, por Hassan al-Bannã, a Irmandade Muçulmana expandiu-se pelo Oriente Médio. Seus integrantes acreditavam que "a bandeira do Islã deve cobrir o gênero humano e que cada muçulmano tem por missão educar o mundo segundo os princípios do Islã”. E deviam prometer lutar para realizar essa missão enquanto vivessem, para isso, se necessário, sacrificando tudo que possuíssem. ${ }^{11}$ A Irmandade Muçulmana envolveuse ativamente na guerra árabe-israelense de 1948, depois na guerra antibritânica no Canal de Suez (1951-52), apoiou o golpe de Nasser (1952), mas acabou opondo-se ao poder de Nasser a partir de 1954. Muitos de seus membros foram aprisionados e executados, em 1954 e 1966. Os que restaram foram libertados no período 19711973, reorganizaram o movimento que gerou grupos extremistas dissidentes, responsáveis por ações violentas no Egito em 1974, 1977 e 1981 (assassinato do presidente Anwar al-Sadat, considerado um traidor da religião porque assinara 0 Tratado de Camp David, reconhecendo Israel).

Em 1982, membros da Irmandade Muçulmana iniciaram uma revolta em Hama, na Síria, matando autoridades do governo local e suas famílias. 0 presidente Hafez Assad, muçulmano alawita, ordenou repressão brutal aos revoltosos. 0 Exército sírio destruiu a cidade, matando 20 mil pessoas. Logo em seguida à ação que arrasou Hama, o governo realizou execuções em massa. No ano seguinte, o xeque Saad e-Din el'Alami de Jerusalém publicou uma fatwa ("decreto religioso") prometendo a qualquer muçulmano que assinasse o "infiel" Hafez Assad um "lugar no Paraíso pela eternidade".

No Sudão, quando o país se libertou da Grã-Bretanha, em 1956, recomeçaram os conflitos entre os muçulmanos do norte e os cristãos e animistas do sul. A partir de 1955, os sulistas, temendo a imposição sobre eles de instituições islâmicas, rebelaram-se. Seguiu-se uma guerra entre norte e sul que matou cerca de 500 mil pessoas e durou até 1972, quando se chegou a uma trégua. Porem, em 1983, a matança recomeçou, principalmente porque o presidente Gaafar Muhammad al-

${ }^{11}$ Massoulié, F. Os conflitos do Oriente Médio. São Paulo: Ática, 1994. p. 29. 
Nimeiry submeteu o país inteiro à shariah. As lutas entre os cristãos e as tropas do governo causaram baixas enormes, destruição de povoadas e ondas de fome. A deposição de Nimeiry, em 1985, não pôs fim ao conflito, porque seu sucessor, Sadiq al-Mahdi, não aboliu a shariah. A guerra civil recrudesceu e, com ela, a fome. Até hoje a luta prossegue, e já matou mais de um milhão de pessoas no Sudão.

Mesmo sendo um país marcado por grande rigor islâmico, a Arábia Saudita, desde os anos 1980, vive sobressaltada pela ação de radicais religiosos sunitas exiitas. No ano de 1979, o sunita Juhaiman al Otaiba proclamou-se um novo Mahdi que ia "limpar" a Arábia Saudita, expulsando todos os não-mulçumanos e abolindo a televisão e a instrução para as mulheres. Em novembro de 1979, Juhaiman e cerca de 200 seguidores invadiram a Grande Mesquita de Meca onde estavam 40 mil peregrinos para o bajj ("o retorno ao relicário") anual. 0 Exército saudita recebeu autorização para retomar a mesquita, seguindo-se nove dias de lutas palmo a palmo dentro do templo. Morreram 255 soldados, fanáticos e peregrinos. Juhaiman e seus seguidores restantes foram capturados, julgados e sentenciados à morte por um tribunal religioso secreto. No mesmo ano, os xiitas desafiaram o governo wahabi durante o festival de Ashura, que comemora o martírio de Hussein, neto de Mohammed. Apesar da proibição, os xiitas realizaram autoflagelações. A polícia interveio e a multidão reagiu, quebrando lojas e incendiando automóveis. Nesses tumultos morreram 17 xiitas. Mais mortes aconteceram depois que o Exército saudita foi enviado à região para impor a ordem. Conflitos envolvendo radicais muçulmanos, durante o hajj a Meca, voltaram a ocorrer em 1987 (cerca de 400 mortos) e 1989, ambos deflagrados por terroristas xiitas.

Atualmente, a Arábia Saudita é palco de uma espécie de guerra civil subterrânea que opõe a família real wahabi a muçulmanos ainda mais fundamentalistas, ligados à al-Qaeda de Osama bin Laden; esses últimos consideram que a monarquia saudita é "infiel", porque aliou-se aos Estados Unidos. O paísé, portanto, alvo regular de atentados de extremistas religiosos.

De meados da década de 1970 até o início dos anos 1990, o Líbano se dividiu pela fé. Cristãos maronitas, muçulmanos xiitas e sunitas começaram a formar milícias e enfrentaram-se numa guerra civil que destruiu o país, causando mais de 130 mil mortes. Beirute foi dividida pela "linha verde", separando os setores cristão e muçulmano da cidade. Franco-atiradores cristãos e homens-bomba sunitas vitimaram milhares de civis; ocidentais de várias nacionalidades foram assassinados e/ou seqüestrados. Na guerra civil libanesa surgiram grupos radicais: o Hezbollah ("Partido-de Deus"), facção xiita ligada ao Irã; a milícia xiita Amal, ligada à Síria; a milícia Tawheed, de fundamentalistas 
sunitas; e a Jihad Islâmica, de orientação xiita. Esses grupos empregam o terrorismo como instrumento de luta política e continuam bastante ativos no Oriente Médio. 0 Hezbollah e a Jihad Islâmica promovem atentados suicidas e ataques armados contra alvos israelenses, tanto a partir de territórios palestinos quanto do sul do Líbano.

A maior vitória dos fundamentalistas islâmicos foi a conquista do Irã, em 1979. A Revolução Iraniana, liderada pelo aiatolá Khomeini, implantou no país uma teocracia xiita. Os mullas (o clero xiita) assumiram o poder no Parlamento, aprovaram leis islâmicas rígidas, fecharam o país para o 0cidente e inundaram o Irã com slogans de ódio contra os "infiéis". Em meio à guerra contra o Iraque, resultante da invasão do Irã pelas tropas de Saddam Hussein, o aiatolá Khomeini disse a seu povo, em dezembro de 1984:

"A guerra é uma bênção para o mundo e para todas as nações. É Deus que incita os homens a lutar e a matar. 0 Corão diz: 'Lute até que toda corrupção e toda rebelião tenham cessado'. As guerras que o Profeta liderou contra os infiéis foram uma bênção para toda humanidade (...) 0 Corão diz: 'Guerra, guerra até a vitória’(...) Os mulas de corações corruptos que dizem que tudo isso é contrário aos ensinamentos do Corão são indignos do Islã(...) Matar os descrentes é uma das maiores missões do homem". ${ }^{12}$

0 "governo de Deus na terra" estabelecido por Khomeini promoveu torturas e execuções, que caíram sobre os discordantes do regime e também sobre os baha'is, muitos deles, inclusive mulheres e crianças, enforcados em público. A seita foi oficialmente declarada proscrita, seus integrantes expulsos de seus empregos, escolas e lares, porque os aiatolás os consideravam "pervertidos", "instrumentos de Satã e seguidores do diabo e das superpotências". Cerca de 40 mil baha'is fugiram do Irã. Em 1989, Khomeini lançou uma convocação para o assassinato do escritor inglês Salman Rushdie, autor do livro Versos Satânicos, que havia sugerido que as revelações a Mohammed contidas no Corão não vieram do céu. Rushdie passou a viver escondido, sob proteção da polícia inglesa, e muitos governos ocidentais reduziram suas relações diplomáticas com o Irã.

Convém anotar que o impulso religioso fundamentalista que dirigiu a Revolução Iraniana respondia a um processo de ocidentalização do país, levado a cabo pela dinastia Pahlevi, grande aliada dos americanos. 0 governo do xá Reza Pahlevi era caracterizado pela corrupção e forte repressão, a cargo da polícia secreta Savak. Os xiitas conservadores, desejosos do retorno à severa lei islâmica, souberam canalizar e instrumentalizar o

${ }_{12}$ Haught, J. A. Perseguições religiosas. Rio de Janeiro: Ediouro, 2003. p. 186. 
descontentamento da maioria do povo. No curso da história, religião e política freqüentemente aparecem imbricados.

Também a África é conturbada pela ação de grupos islâmicos fundamentalistas. Na Nigéria, os confrontos muçulmanos-contra-muçulmanos arrastam-se desde a década de 1980 . 0 país está potencialmente dividido, porque nas regiões do norte cresce a aplicação da shariah pelas autoridades e líderes religiosos locais, despertando contra-reações do governo e repúdio internacional. Em 2000, choques entre muçulmanos e cristãos causaram 2 mil mortes em Kaduna, no norte do país. Em 2002, novos conflitos ocorreram em Kaduna, dessa vez por causa de um concurso de beleza, provocando 200 mortes. Na Tunísia e na Argélia, partidos islâmicos fundamentalistas vêm ganhando força e praticam massacres no interior, além de atentados terroristas nas capitais. Grupos muçulmanos armados também atuam em diversas regiões da Ásia, como a Indonésia, as Filipinas e a Chechênia.

Por que esta efervescência fundamentalista no mundo islâmico? A resposta para esta pergunta deve levar em consideração pelo menos três aspectos. Conforme Gellner, o fundamentalismo islâmico está associado à rejeição dos muçulmanos ao processo de secularização, o que alimenta a criação de diversos movimentos que propõem a volta à Idade de Ouro, período que corresponderia ao advento do Profeta até o califado Abássida. ${ }^{13}$ 0 segundo aspecto refere-se ao fato de que o Islã é uma religião que pretende completar a revelação divina, porque Mohammed é o último mensageiro de Deus. Por isso, os muçulmanos consideram as mensagens reveladas anteriormente como distorcidas pelos seus seguidores. 0 terceiro aspecto é a noção fundamental de que religião e política são interligadas, a ponto da lei abarcar tanto a dimensão temporal quanto espiritual. Por ter sido revelada por Allah, não cabe aos teólogos ou aos fiéis questionar a lei. Mais do que isso, a shariah subordina o poder executivo ao legislativo e os ulama ("os doutores da lei") têm o dever de serem responsáveis pela cobrança do cumprimento da observância da fé islâmica. A combinação dos fatores citados favorece o constante surgimento de interpretações fundamentalistas dos textos sagrados e das tradições islâmicas, em resposta a problemas políticos e sociais novos.

É claro que a incapacidade do Estado de dar melhor condição de vida ao povo, fato que se verifica na ampla maioria dos países muçulmanos, abre espaço para a mensagem fundamentalista. Como a maioria das sociedades muçulmanas está cada vez mais pobre, debatendo-se no subdesenvolvimento e amargando humilhações geopolíticas desde 0

13 Cf. GeLLner, E. Op. cit., pp $14 s s$. 
século XIX, muitos dos seus integrantes sentem a necessidade de uma "defesa ideológica" contra a incerteza e o ressentimento que os insucessos históricos colocaram sobre os ombros dessas sociedades. 0 fundamentalismo islâmico, baseado na ideologia da vitimação e na valorização de teorias conspiratórias, fornece uma resposta simples e direta para aquela necessidade.

0 radicalismo islâmico contemporâneo modernizou o conceito de jih ad, que era visto apenas como elemento de defesa dos muçulmanos, dotando-o de uma função de ataque e, também, de luta intelectual pela causa de Deus, isto é, a produção de estudos teológicos e de obras que conclamam os muçulmanos a se posicionarem diante do avanço dos valores ocidentais. Os radicais estão recuperando e cultuando os "heróis" muçulmanos como o Mabdi do Sudão. Para recrutar novas levas de seguidores, eles também têm sabido utilizar o antagonismo contra a cristandade ocidental que está amplamente presente no mundo muçulmano, notadamente no Oriente Médio. Afinal, no imaginário de diversos povos islâmicos, sobrevivem uma longa história de interações conflituosas com o Ocidente e percepçoes negativas referentes aos cristãos. Dessa forma, os radicais bloqueiam as ações das elites modernizantes e das correntes intelectuais laicas dos países muçulmanos, dificultando o diálogo com o Ocidente. 0 reconhecimento da virulência dos grupos fundamentalistas islâmicos radicais não deve levar, contudo, a adoção de uma atitude alarmista, como a que insiste no "choque de civilizações". Isso porque "a maioria dos muçulmanos não são fundamentalistas, e a maioria dos fundamentalistas não são terroristas", embora numerosos terroristas atuais sejam muçulmanos e se orgulhem disso. ${ }^{14}$

\section{O Futuro do Fanatismo}

0 revival religioso nos Estados Unidos e o fundamentalismo militante dos grupos evangélicos neste país, bem como o avanço dos movimentos islâmicos "integristas" na Árica, no Oriente Médio e na Ásia sugerem que a aposta iluminista está definitivamente

${ }^{14}$ LEwIs, B. Os assassinos: os primórdios do terrorismo no islã. Rio de Janeiro: Jorge Zahar, 2003. p. 137. Acerca do fundamentalismo islâmico ver também: Demant, P. O mundo muçulmano. São Paulo: Contexto, 2004; Esposito, J. El desafio islamico. Madrid: Acento Editorial, 1996; LewIs, B. The crisis Lewis, B. 0 que deu errado no Oriente Médio? Rio de Janeiro: Jorge Zahar, 2002; Au, T. Confronto de fundamentalismos. Rio de Janeiro: Record, 2002; RashiD, A. Jibad. São Paulo: Cosaq \& Naify, 2003; SAID, E. Orientalismo: 0 Oriente como invenção do Ocidente. São Paulo: Companhia das Letras, 1990; SaID, E. Cultura e Imperialismo. São Paulo: Companhia das Letras, 1995. 
perdida. A perda de influência social da religião, tomando-se em conta estes sinais, não estáse verificando na maior parte do mundo. Então, cabe perguntar: o futuro do fanatismo religioso é promissor? Até onde a vista alcança, há razões para crer que o fanatismo religioso, potencializado pela globalização, continuará produzindo episódios de intolerância e violência.

A modernidade avassaladora, competitiva, produtivista e excludente promove por toda parte a corrosão das identidades individuais e coletivas que davam sentido para a vida das pessoas e dos grupos sociais e abala profundamente a tradição que fornecia 0 elemento de coesão social em muitos lugares do planeta. A modernidade gera "desencaixes" que causam sofrimento e desorientação, tanto no plano individual quanto no social. Freqüentemente, estes desencaixes são vistos como sintomas de uma Era de Decadência que estaria prestes a levar de roldão grupos sociais e sociedades inteiras. Como forma de enfrentar essa situação, a reflexividade individual e coletiva esforça-se para gerar "reencaixes", isto é, para construir traços e relações pessoais e coletivas relativamente estáveis que reafirmem o pertencimento do indivíduo a um grupo, uma classe, uma religião, uma etnia, etc. 0 fundamentalismo parece ser um caso de re-engate reflexivo com a tradição, uma resposta direta aos problemas surgidos com a modernidade.

Os movimentos religiosos fundamentalistas realizam a recuperação seletiva de doutrinas, crenças e práticas de um passado tido como sagrado. Esses elementos são modificados e sancionados pragmaticamente: servem, por um lado, para mobilizar a resistência ao avanço das idéias, das práticas e dos valores estranhos à comunidade e, de outro lado, para estabelecer pautas de reivindicações e inovações doutrinárias. Dessa forma, numa perspectiva sociológica, os movimentos fundamentalistas contemporâneos operam, paradoxalmente, a modernização da tradição e a redefinição do pertencimento (do indivíduo e do grupo) à modernidade. Eles são parte indissociável do processo de globalização assimétrica.

Nas sociedades afluentes, nas quais campeia o consumismo, homens e mulheres para os quais foi negado o sucesso pessoal, restando-lhes somente o lugar de "perdedores" - a condição de outro na gíria do capitalismo yuppie -, ficam suscetíveis ao apelo de seitas e cultos "destrutivos" e de grupos evangélicos fundamentalistas, como ocorre nos Estados Unidos. No interior dessas novas comunidades, o indivíduo salva seu próprio eu da dor e da anomia. Mas, para isso, submete-se ao comando de um líder carismático e aceita plenamente a verdade única do líder, que é o fator de coesão comunitária. Essa verdade, revelada ao "fiel" e apenas a ele, restitui ao desvalido a capacidade de se situar na nova ordem mundial, e, simultaneamente, transforma muitas vezes as pessoas que não 
integram a nova comunidade em inimigos. Como um carrasco transformado em vítima, teria a religião se tornado nas sociedades capitalistas avançadas o que o sexo era para os vitorianos: um impulso natural recalcado, condenado a "retornar" sob formas truculentas e rancorosas?

Nas sociedades tradicionais afetadas por contatos com o Ocidente, onde ocorreram a destruição de conjuntos culturais e institucionais seculares e o enfraquecimento das formas locais de solidariedade, sem que essas sociedades tivessem logrado uma inserção apropriada na nova ordem mundial, um conjunto crescente de indivíduos experimenta condição terrível: não é parte do novo e nem vive à sombra protetora da tradição. Desesperançados e não raro desesperados, esses indivíduos deixam-se seduzir por aqueles que oferecem a causa do retorno à tradição. Tornam-se presas fáceis do radicalismo fundamentalista.

Num caso como no outro, pululam grupos novos, militantes e puritanos, dotados de características comuns. Tais grupos dão origem a comunidades rigorosamente ascéticas e impõem códigos morais estritos e mesmo regressivos a seus seguidores. Além disso, eles rejeitam a moderna lógica científica e grande parte dos valores da modernidade, vivenciando uma religião sentimental e simplificada, que persegue fervorosamente as virtudes da "pureza" e da "lealdade". Essa religião radical costuma produzir o revigoramento das noções de sacrifício e de martírio, o que faz do suicídio e da disposição de destruir, evidências de fé. Por conseguinte, talvez mais no Oriente do que no Ocidente, as diferenças religiosas adquirem renovado potencial para gerar fanatismos e violências, e o fanatismo e a violência alimentam o zelo religioso. 